\title{
EFFECT OF PARABIOSIS OR UTERINE EXTRACTS ON PSEUDOPREGNANCY IN HYSTERECTOMIZED RATS
}

\author{
GUY H. KIRACOFE* AND HAROLD G. SPIES \\ Department of Animal Husbandry, Kansas State University, \\ Manhattan, Kansas, U.S.A.
}

(Received 27th Fuly 1965, revised 15th February 1966)

\begin{abstract}
Summary. Regression of the corpora lutea was hastened in hysterectomized-pseudopregnant rats by parabiotic union with ovariectomized partners. Hysterectomized-pseudopregnant rats paired either with hysterectomized-pseudopregnant or with normal cycling partners had periods of pseudopregnancy similar in length to those in unpaired hysterectomized-pseudopregnant control females. Injections of ether-soluble extracts or of lyophilized homogenates of oestrous rat uteri did not shorten pseudopregnancy in hysterectomized rats.
\end{abstract}

The technique of parabiosis (Bunster \& Meyer, 1933) was employed to test for presence of a luteolysin from normal or ovariectomized rats that could cross the parabiotic union and influence the life-span of corpora lutea in pseudopregnant or hysterectomized-pseudopregnant partners. Sprague-Dawley females, 60 to 80 days old, were paired as follows: In Group 1, rats ovariectomized in di-oestrus were combined 4 or 5 days later with intact pseudopregnant ones which were in oestrus (Day 1) at the time of the operation; in Group 2, intact rats in oestrus were combined with hysterectomized-pseudopregnant ones on Day 4 or 5; in Group 3, pseudopregnant females hysterectomized immediately before parabiosis on Days 3, 4 or 5 were combined with rats ovariectomized 4 or 5 days previously; and in Group 4, both pseudopregnant partners were hysterectomized and paired on Day 5. Pseudopregnancy was induced by cervical stimulation with a glass rod at late pro-oestrus or early oestrus. Rats showing vaginal cornification before Day 7 were discarded. Several of the largest corpora lutea in the hysterectomized- and intact-pseudopregnant partners were marked with India ink before joining, using the method described by Spies, Gier \& Wheat (1964). Most rats were killed on the day after the first vaginal cornification following pairing or at the expected end of pseudopregnancy for the experimental parabiont; however, in a few cases repeated vaginal smears were followed. At autopsy ovaries were fixed in Bouin's fluid for histological study. Sections were cut at $8 \mu$ and stained with Mallory's triple stain. The presence of India ink verified the age of the corpus

* Present address: Department of Anatomy, University of Kentucky Medical Center, Lexington, Kentucky. 
luteum under investigation since circulating oestrogens of either parabiont could reach levels sufficient to confuse the vaginal smear of the experimental parabiont (Biddulph, Meyer \& Gumbreck, 1941).

Fifteen rats of the same age and strain as described in the four parabiosis groups were hysterectomized following cervical stimulation at early oestrus and divided into three equal groups to test for evidence of a uterine luteolysin. Each rat in one group received ether-soluble extracts, those in a second group lyophilized homogenates of two uteri taken from oestrous rats, and rats in a third group served as saline-injected controls. Daily injections of $0.2 \mathrm{ml}$ were given subcutaneously on Days 8 to 18 after cervical stimulation. Uteri were

\section{TABLE 1}

LENGTH OF PSEUDOPREGNANCY IN HYSTERECTOMIZED (HYST) AND INTACT RATS AFTER INJECTIONS OF UTERINE EXTRACTS OR PARABIOTIC UNION WITH OVARIECTOMIZED, HYST-PSEUDOPREGNANT OR INTACT CYGLING RATS

\begin{tabular}{|c|c|c|c|}
\hline Group & Treatment & No. of rats & $\begin{array}{l}\text { Vaginal cycle length } \\
\text { (Mean days } \pm \text { S.E.) }\end{array}$ \\
\hline $\begin{array}{l}1 \\
2 \\
3 \\
4 \\
- \\
-\end{array}$ & $\begin{array}{l}\text { Intact-pseudopregnant paired } \\
\text { with ovariectomized } \\
\text { Hyst-pseudopregnant paired } \\
\text { with intact cycling } \\
\text { Hyst-pseudopregnant paired } \\
\text { with ovariectomized } \\
\text { Hyst-pseudopregnant paired } \\
\text { with hyst-pseudopregnant } \\
\text { Unpaired hyst-pseudopregnant } \\
\text { control } \\
\text { Unpaired hyst-pseudopregnant } \\
\text { plus uterine extracts }\end{array}$ & $\begin{array}{r}3 \\
3 \\
13 \\
8 \\
5 \\
10\end{array}$ & $\begin{array}{l}11 \dagger \\
17 \cdot 3 \pm 10 \\
13 \cdot 4 \pm 3 \cdot 7 * \\
18 \cdot 1 \pm 6 \cdot 8 \ddagger \\
18 \cdot 4 \pm 4 \cdot 1 \\
20 \cdot 5 \pm 6.5\end{array}$ \\
\hline
\end{tabular}

* Significantly different $(P<0.05)$ from Hyst-pseudopregnant paired with Hyst-pseudopregnant group by Student's ' $t$ ' test. Other means were not significant from the unpaired Hyst-pseudopregnant or Hyst-pseudopregnant paired with Hyst-pseudopregnant groups.

$\dagger$ Two of the three rats did not return to oestrus; killed on Day 13 (corpora lutea regressing) and Day 20 (corpora lutea regressed). All follicles were atretic.

$\ddagger$ One rat did not return to oestrus and vaginal smear data were not included; when killed on Day 27 the corpora lutea had regressed and follicles were atretic.

either frozen and lyophilized or chopped into small pieces and extracted fresh with ether. Lyophilized uteri were suspended in $2.0 \mathrm{ml}$ of saline while ether extracts were evaporated and dissolved in $2.0 \mathrm{ml}$ of sesame oil for injection. Daily vaginal smears were recorded, and the day on which predominantly cornified or nucleated cells were found was considered to be the end of pseudopregnancy. Data from rats showing vaginal cornification before Day 7 were excluded.

The average periods of pseudopregnancy for all the experimental groups are reported in Table 1. Histological data indicated that luteal regression had either begun (presence of marked regressing corpora lutea) or occurred in all the pseudopregnant parabionts killed at the first vaginal cornification following 
pairing. Pseudopregnant periods averaged 13.4 days in hysterectomized rats paired with ovariectomized partners, compared with 17.3, 18.1 and 18.4 days for hysterectomized rats paired with normal cycling partners, hysterectomizedpseudopregnant partners and unpaired hysterectomized rats, respectively. Greep \& Jones (1950) demonstrated that $\mathrm{LH}$ injected into a parabiont rat could cross the parabiotic union in quantities sufficient to induce luteinization in its partner. Rothchild (1965) demonstrated the luteolytic effect of a continuous supply of $L H$ in the rat, and a similar effect of $L H$ has been reported in the rabbit (Stormshak \& Casida, 1964; Spies, Coon \& Gier, 1966). Ramirez \& McGann (1963) showed an increase in plasma and pituitary LH in ovariectomized rats above that present in cycling controls. Therefore, it appears feasible that an increased secretion of gonadotrophins from the ovariectomized partner may have crossed the parabiotic union and hastened luteolysis in the hysterectomized-pseudopregnant partner.

Two intact-pseudopregnant rats paired with ovariectomized rats and one hysterectomized-pseudopregnant rat with a hysterectomized-pseudopregnant partner failed to return to oestrus before autopsy on Days 13, 20 and 27, respectively. Histological data showed the corpora lutea had regressed. New ovulations had not occurred and all follicles appeared atretic in these three rats.

Injections of ether-soluble extracts and lyophilized uterine homogenates of oestrous rat uteri gave no indication of shortening pseudopregnancy. Vaginal cycles averaged 20.6 and 20.4 days for the rats injected with ether-soluble extracts and lyophilized homogenates, respectively. These data are in agreement with those of Malven \& Hansel (1965) who failed to demonstrate a luteolysin in pseudopregnant rats given aqueous and ether extracts of bovine endometrium.

This investigation was supported by funds provided in Grant HD-00392 from the National Institutes of Health. Contribution No. 334, Department of Animal Husbandry, Kansas Agricultural Experimental Station, Manhattan.

\section{REFERENCES}

Biddulph, C., Meyer, R. K. \& Gumbreck, L. G. (1941) Quantitative studies of estrogen transfer between parabiotic rats in relation to the effect of $p p^{\prime}$-dihydroxy-a-b-diethylstilbene and the secretion of the gonadotropic complex. F. exp. Zool. 88, 17.

Bunster, E. \& Meyer, R. F. (1933) An improved method of parabiosis. Anat. Rec. 57, 339.

Greep, R. O. \& Jones, I. C. (1950) Steroid control of pituitary function. Recent Prog. Horm. Res. 5, 197.

Malven, P. V. \& Hansel, W. (1965) Effect of bovine endometrial extracts, vasopressin and oxytocin on the duration of pseudopregnancy in hysterectomized and intact rats. F. Reprod. Fert. 9, 207.

RamiRez, V. D. \& MCCANN, S. M. (1963) Comparison of the regulation of luteinizing hormone (LH) secretion in immature and adult rats. Endocrinology, 72, 452.

RoтнсніLd, I. (1965) The corpus luteum-hypophysis relations. The luteolytic effect of luteinizing hormone $(\mathrm{LH})$ in the rat. Acta endocr., Copenh. 49, 107.

Spres, H. G., Coon, L. L. \& Gier, H. T. (1966) Luteolytic effect of LH and HCG on the corpora lutea of pseudopregnant rabbits. Endocrinology, 78, 67.

SpIes, H. G., Gier, H. T. \& WhEAT, J. D. (1964) Ovarian changes in hormone treated hysterectomized and cycling guinea pigs. Trans. Kans. Acad. Sci. 67, 517.

Stormshak, F. \& Casida, L. E. (1964) Effect of gonadotropin on corpora lutea of pseudopregnant rabbits. Endocrinology, 75, 321. 